\title{
Collagen Alpha-2(IV) Chain
}

National Cancer Institute

\section{Source}

National Cancer Institute. Collagen Alpha-2(IV) Chain. NCI Thesaurus. Code C152984.

Collagen alpha-2(IV) chain (1712 aa, $168 \mathrm{kDa}$ ) is encoded by the human COL4A2 gene.

This protein is involved in basement membrane formation. 